December 2020

\title{
Rural Outreach Services Enrich Seniors' Lives
}

Claire C. Goldstein

San Jose State University, clairegoldstein90@gmail.com

Follow this and additional works at: https://scholarworks.sjsu.edu/ischoolsrj

Part of the Scholarly Communication Commons, and the Scholarly Publishing Commons

\section{Recommended Citation}

Goldstein, C. C. (2020). Rural Outreach Services Enrich Seniors' Lives. School of Information Student Research Journal, 10(2). https://doi.org/10.31979/2575-2499.100206 Retrieved from https://scholarworks.sjsu.edu/ischoolsrj/vol10/iss2/6

This article is brought to you by the open access Journals at SJSU ScholarWorks. It has been accepted for inclusion in School of Information Student Research Journal by an authorized administrator of SJSU ScholarWorks. For more information, please contact scholarworks@sjsu.edu. 


\section{Rural Outreach Services Enrich Seniors' Lives}

\section{Keywords}

library outreach, rural public libraries, seniors

About Author

Claire C. Goldstein graduated with an MLIS from San Jose State University in May 2020. 


\section{A Review of: Sikes, S. (2020). Rural public library outreach services and elder users: A case study of the Washington County (VA) Public Library. Public Library Quarterly, 39(4), 363-388. https://doi.org/10.1080/01616846.2019.1659070}

\section{Structured Abstract}

Objective - To investigate the information needs of senior rural public library users and the impact of outreach services on their lives.

Design - Qualitative case study.

Setting - A rural Appalachian public library system in Virginia.

Subjects - Twenty-four seniors who attended community social groups receiving outreach services and six library staff members with in-depth knowledge of outreach services.

Methods - The seniors participated in four focus groups at two locations, with each focus group comprising six participants. Staff members were given semi-structured narrative interviews. Question guides, field-note templates, audio recording, and transcription were all used to gather accurate data. Grounded theory principles as well as open, axial, and selective coding were employed to isolate themes and categories within participant responses for data analysis.

Main Results - Analysis isolated three major areas of need for service users:

- entertainment and intellectual stimulation

- transportation and mobility issues

- technology and internet access

There was a gap between service users' and staff members' perception of user needs. Staff identified internet access as a serious issue, while users expressed little interest in technology. Users emphasized their desire for entertainment, while staff were less focused on this area of need. Both users and staff expressed concern about lack of or limited transportation as a barrier to information access. With regard to impact, it was found that outreach services provided significant positive impacts for elder users; most notably increased quality of life, social outlets, and connection to the wider community via the library as a community center.

Conclusion - The researcher argued that this study demonstrates the library outreach services' ability to meet users' needs and positively impact their lives.

\section{Commentary}

This study joins overlapping bodies of literature on senior library users, outreach services, and rural public libraries. As populations in the United States and worldwide continue to age, seniors are becoming an increasingly significant subset of library users. Although providing information access, programs, and services to this diverse and often multiply disadvantaged population is a growing concern, research on the effectiveness of current library services for older adults remains limited. Like the library system in this study, over $40 \%$ of U.S. public libraries are both small and rural (Swan et al., 2013). Some evidence suggests, though inconclusively, that U.S. rural libraries tend to both have 
larger senior user populations and target fewer services toward them (Lenstra et al., 2019, p. 740). All libraries that serve older adults can benefit from understanding their specific needs and the ways to better meet them; but such research is especially beneficial for smaller libraries with fewer resources such as rural public libraries. In an era when many libraries have to fight tooth and claw for funding, it is necessary both to demonstrate the value of library services and ensure that the services provided are appropriate and efficient.

Assessed per Glynn's (2006) critical appraisal checklist, and as the author indicates, there are several significant limitations to this study. The small sample size was one drawback. Participants were drawn from a weekly social group, restricting the evaluation to the number of those in attendance. Not being homebound or residing in an assisted living facility were prerequisites to participate in the study, which leaves out a considerable portion of seniors who do fit those categories and are in need of receiving outreach services. Furthermore, only one case study was conducted because of "limitations of scope and time" (p. 374). Future directions for research are infrequently discussed; with the concentration focused instead on showing the existing program's worth.

An interesting standout in the results is the disparity in perceptions between service users and library staff on the topic of technology and internet access. While staff expressed that technological access was an important concern for seniors, users focused much more on the value of entertainment and intellectual stimulation (e.g., books, puzzles, movies, etc.) that they would not be able to access without the library. Technology cropped up as a general concern twice, and as a specific concern in relation to one user's preference for e-readers; again, tying into the theme of entertainment ( $p$. 380). These findings indicate that rural public library systems with similar user populations may wish to reassess their senior services, determining whether they should shift resources from technological access to entertainment options. Also brought into focus, are the roles that technology and internet access play for older adults in generalwhat they want them for and how they use them. How should library services look in a community where seniors mostly use the internet as a source of entertainment, versus one where they mostly use it for email communication, health information, or shopping? Further study could elucidate these questions.

\section{References}

Glynn, L. (2006). A critical appraisal tool for library and information research. Library Hi Tech, 24(3), 387-399. https://doi.org/10.1108/07378830610692154

Lenstra, N., Oguz, F., \& Duvall, C. S. (2019). Library services to an aging population: A nation-wide study in the United States. Journal of Librarianship and Information Science, 52(3), 738-748. https://doi.org/10.1177/0961000619871596

Swan, D. W., Grimes, J., \& Owens, T. (2013). The state of small and rural libraries in the United States (Research Brief No. 5). Institute of Museum and Library Services. https://www.imls.gov/publications/research-brief-no-5-state-small-andrural-libraries-united-states 